\title{
PENGGUNAN REGRESI LINEAR UNTUK MENGETAHUI VARIABEL PENGARUH PADA KEKUATAN LERENG HIGHWALL PIT ALFA - PT ARUTMIN INDONESIA TAMBANG KINTAP
}

\author{
Aryoseno ${ }^{1)}$, Prima Laksana ${ }^{2)}$, Steffani Kurnia Viona ${ }^{3)}$ \\ 1) Geology \& Geotechnical Supervisor, PT Arutmin Indonesia - Tambang Kintap \\ 2) Senior Geotechnical Engineer, PT Arutmin Indonesia - Balikpapan \\ 3) Teknik Pertambangan, Institut Teknologi Bandung
}

\begin{abstract}
ABSTRAK
Penambangan di area blok 73-76 Pit Alfa, PT Arutmin Indonesia - Tambang Kintap belum memasuki fase final (mined out). Area ini saat ini terendam oleh air sehingga belum bisa dilakukan operasi lanjutan di area tersebut. Untuk melanjutkan penambangan di area tersebut, dibutuhkan suatu penilaian Faktor Keamanan (FK) dari lereng tambang. Metode statistika berupa regresi linier sederhana digunakan untuk mengetahui variabel yang paling berpengaruh terhadap kekuatan lereng. Regresi linier sederhana adalah Metode Statistik yang berfungsi untuk menguji sejauh mana hubungan sebab akibat antara Variabel Faktor Penyebab terhadap Variabel Akibatnya,. Terdapat tiga variabel yang terlibat dalam penilaian FK ini yaitu elevasi muka air tanah (MAT) yang didapat dari pengamatan berkala dari lubang piezometer yang ada, variabel kedua adalah elevasi air yang menutupi sump / daerah yang akan di-progress serta variabel selanjutnya adalah ketinggian lereng (highwall) tambang. Selanjutnya ketiga variabel tersebut digambarkan dalam persamaan $\mathrm{FK}=\mathrm{Ax}$ (elevasi MAT) $+\mathrm{By}$ (elevasi sump) $+\mathrm{Cz}_{\text {(ketinggian lereng) }}+\mathrm{K}$ dengan hipotesa awal (Ho) variabel bebas tidak berpengaruh terhadap variabel terikat dan hipotesa akhir (H1) berupa variabel bebas memiliki pengaruh terhadap variabel terikat. Dari hasil analisis didapatkan persamaan regresi $F K=-0.0089 x+0.0059 y+(-) 0.026 z+2.2314$ dimana didapatkan variabel utama yang paling berpengaruh terhadap perubahan FK adalah ketinggian lereng. Untuk hasil permodelan lereng dari awal periode penelitian (minggu pertama April 2019) hingga akhir penelitian (minggu ke empat belas atau meinggu kedua Juli 2019), didapatkan trend nilai FK yang cenderung menurun (FK 1.51 - FK 1.22) dimana hal ini disebabkan karena bekerjanya variabel beda tinggi lereng (nilai beda ketinggian semakin besar seiring dengan penurunan level tambang).
\end{abstract}

Kata Kunci : Variabel Pengaruh, Regresi Linier, Faktor Keamanan

\section{A. PENDAHULUAN}

\section{A.1. Latar Belakang}

PT Arutmin Indonesia (PTAI) merupakan salah satu perusahaan yang memiliki ijin Perjanjian Karya Pengusahaan Pertambangan Batubara (PKP2B) dari Pemetintah Republik Indonesia. PTAI memiliki 5 wilayah pertambangan yang tersebar di wilayah Propinsi Kalimantan Selatan yaitu Tambang Senakin, Tambang Satui, Tambang Batulicin, Tambang Asam asam dan Tambang Kintap. Objek penelitian ini berada di Pit Alfa PTAI Tambang Kintap (Gambar 1).

Penambangan di area blok 73-76 Pit Alfa, PT Arutmin Indonesia - Tambang Kintap belum memasuki fase final (mined out). Area ini saat ini terendam oleh air sehingga belum bisa dilakukan finalisasi di area tersebut. Dari lokasi yang ditunjukkan oleh Gambar 2, terdapat 3 (tiga) variabel yang mungkin 
berpengaruh terhadap Faktor Keamanan lereng yaitu, elevasi muka air tanah (MAT), elevasi air di sump / area rencana progress dan ketinggian lereng.

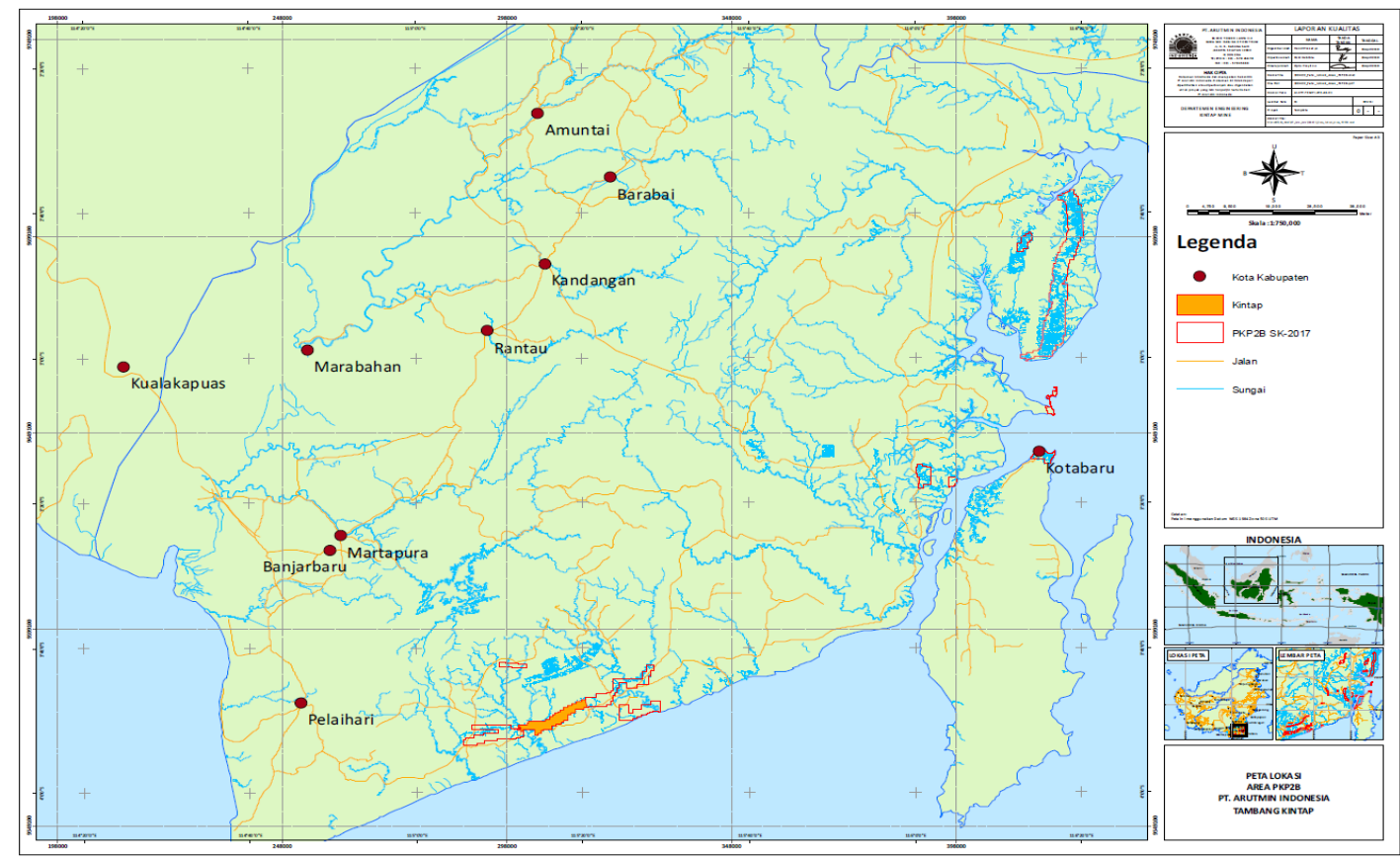

Gambar 1. Lokasi Penelitan - Tambang Kintap

Untuk melanjutkan penambangan di area tersebut, dibutuhkan suatu penilaian Faktor Keamanan (FK) dari lereng tambang (Gambar 2).

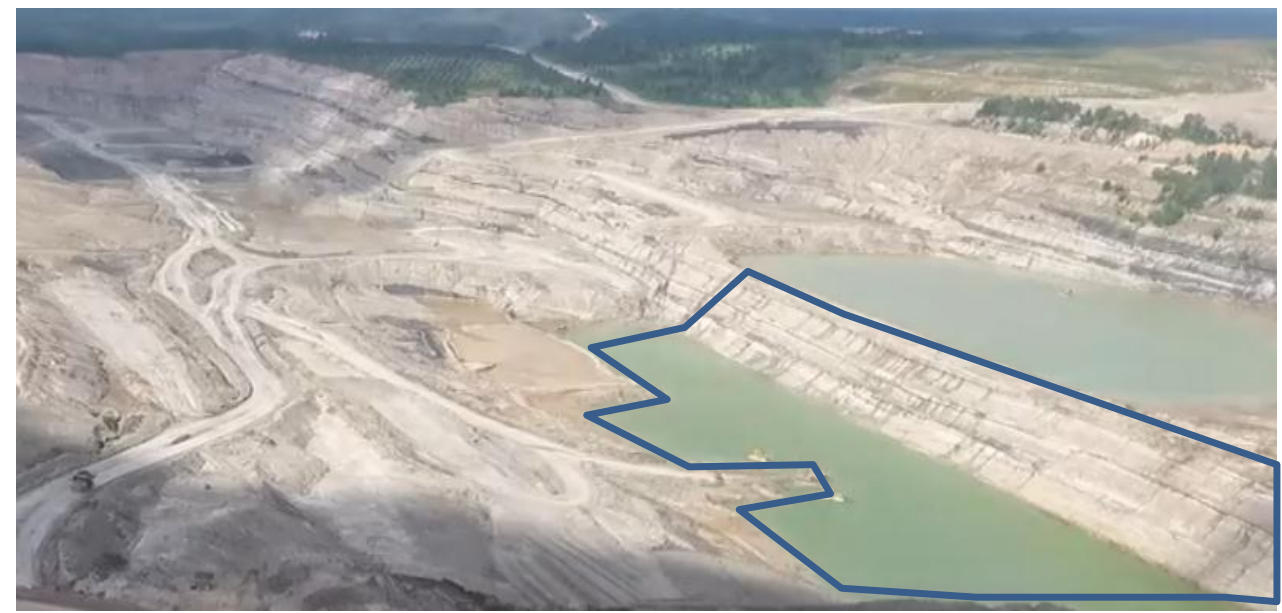

Gambar 2. Lokasi Highwall \& Area Calon Mined Out

\section{A.2. Tujuan}

Tulisan ini memiliki tujuan untuk menentukan variabel utama penyebab perubahan Faktor Keamanan (FK) dari lereng highwall dengan metode statistika sederhana yaitu regresi liniear serta mengetahui 
nilai Faktor Keamanan (FK) dimulai dari periode awal penelitian hingga akhir penelitian (minggu pertama hingga minggu ke empat belas).

\section{A.3. Hipotesis}

Terdapat 3 variabel yang mungkin berpengaruh terhadap nilai FK lereng highwall, serta nilai FK per periode pengamatan akan memiliki hubungan (berbanding lurus ataupun berbanding terbalik) dengan ketiga variabel.

\section{B. LANDASAN TEORI}

\section{B1. Longsoran}

Potensi jenis longsoran yang terbentuk akibat adanya bidang diskontinyu dapat diklasidikasikan menjadi longsoran bidang, longsoran baji, longsoran guling dan longssoran busur (Hoek \& Bray, 1981), (Rai, 1999), (Sulistianto 2012), ilustrasinya ditunjukkan oleh Gambar 3.

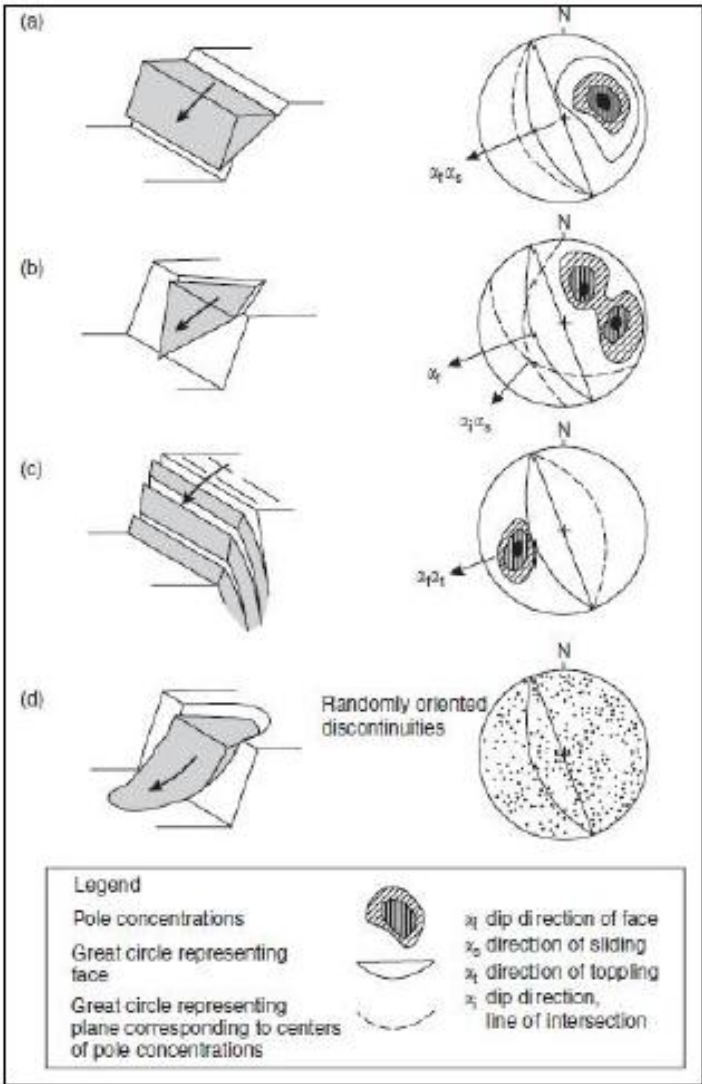

Gambar 3. Ilustrasi Tipe Longsoran, Bidang (a), Baji (b), Guling (c) dan Busur (d)

(Hoek \& Bray, 1981 dalam Wyllie \& Mah, 2004)

Kelongsoran suatu lereng pertambangan tersebut pada umumnya melalui bidang tertentu (slip surface). Menurut Hoek (2000), kestabilan lereng tergantung pada gaya penggerak dan gaya penahan yang bekerja pada bidang gelincir tersebut. Gaya penahan adalah gaya yang menahan agar tidak terjadi kelongsoran, sedangkan gaya penggerak adalah gaya yang menyebabkan terjadinya kelongsoran. Perbandingan antara gaya penggerak dan gaya penahan secara sistematis dapat ditulis dengan rumus sebagai berikut 


$$
\text { Faktor Keamanan }(F K)=\frac{\sum \text { Gaya penahan }}{\text { LGaya Penggerak }}
$$

Dengan ketentuan, jika sesuai teoritis :

FK $>1.0=$ lereng stabil

FK $<1.0=$ lereng tidak stabil

\section{B.2. Statistika}

Analisa regresi adalah salah satu alat yang paling sering digunakan untuk mengevaluasi pengaruh dari suatu variabel bebas atau prediktor/independen terhadap variabel tidak bebas atau respon/dependen (Draper \& Smith, 2011). Analisis regresi ini membantu dalam melakukan proyeksi karakteristik hubungan antar variabel.

Analisis regresi linier berganda bermaksud meramalkan bagaimana keadaan (naik turunnya) variabel terikat (kriterium), bila dua atau lebih variabel bebas sebagai faktor prediator dimanipulasi (dinaik turunkan nilainya). Jadi analisis regresi berganda akan dilakukan bila jumlah variabel independennya minimal 2 (Sugiyono, 2014). Analisis regresi linear berganda memiliki persamaan sebagai berikut.

$$
Y^{\prime}=a+b_{1} X_{1}+b_{2} X_{2}+b_{3} X_{3}+\ldots \text { Konstanta }
$$

Dengan :

$\mathrm{Y}^{\prime} \quad=$ Variabel terikat

$\mathrm{X} \quad=$ Variabel Bebas

a $\quad=$ Konstanta

$\mathrm{b} \quad=$ Koefisien regresi

Dalam penilaian variabel dilakukan uji t, yaitu uji signifikansi parsial. Uji t (Uji Parsial) Uji t (t-test) melakukan pengujian terhadap koefisien regresi secara parsial, pengujian ini dilakukan untuk mengetahui signifikansi peran secara parsial antara variabel bebas terhadap variabel terikat dengan mengasumsikan bahwa variabel bebas lain dianggap konstan (Sugiyono, 2004). Dalam pengujian saignifikansi ditentukan sebuah hipotesis awal yaitu:

H0 : Variabel bebas tidak memengaruhi nilai variabel terikat.

Pernyataan H0 diterima dapat diartikan suatu variabel bebas dapat disimpulkan tidak terlalu memengaruhi nilai variabel terikat, sedangkan jika $\mathrm{H} 0$ ditolak maka suatu variabel bebas memengaruhi nilai dari variabel terikat.

Kesimpulan penerimaan maupun penolakan $\mathrm{H} 0$ didasari oleh nilai dari taraf signifikansi $(P$-Value $) . P$ value adalah besarnya peluang terjadinya kesalahan dalam pengambilan kesimpulan hipotesis dimana peneliti menolak H0 yang seharusnya diterima. Oleh karena itu ketika nilai $P$-value lebih kecil dari nilai taraf kepercayaan sebesar 0.05 maka dapat disimpulkan bahwa $\mathrm{H} 0$ ditolak, dan jika nilai $P$-value lebih besar dari 0.05 maka $\mathrm{H} 0$ diterima.

\section{METODOLOGI PENELITIAN}

Metode penelitian untuk tulisan ini memakai metode analisis kuantitatif, Data yang dipakai adalah data primer berupa pengambilan data elevasi MAT per periode, elevasi sump, ketinggian lereng, data topografi per periode. Sedangkan untuk data sekunder yang dipakai berupa data stratigrafi, serta 
material properties dari litologi penyusun lereng tersebut. Secara ringkas, alur penelitian digambarkan pada Gambar 4 sebagai berikut :

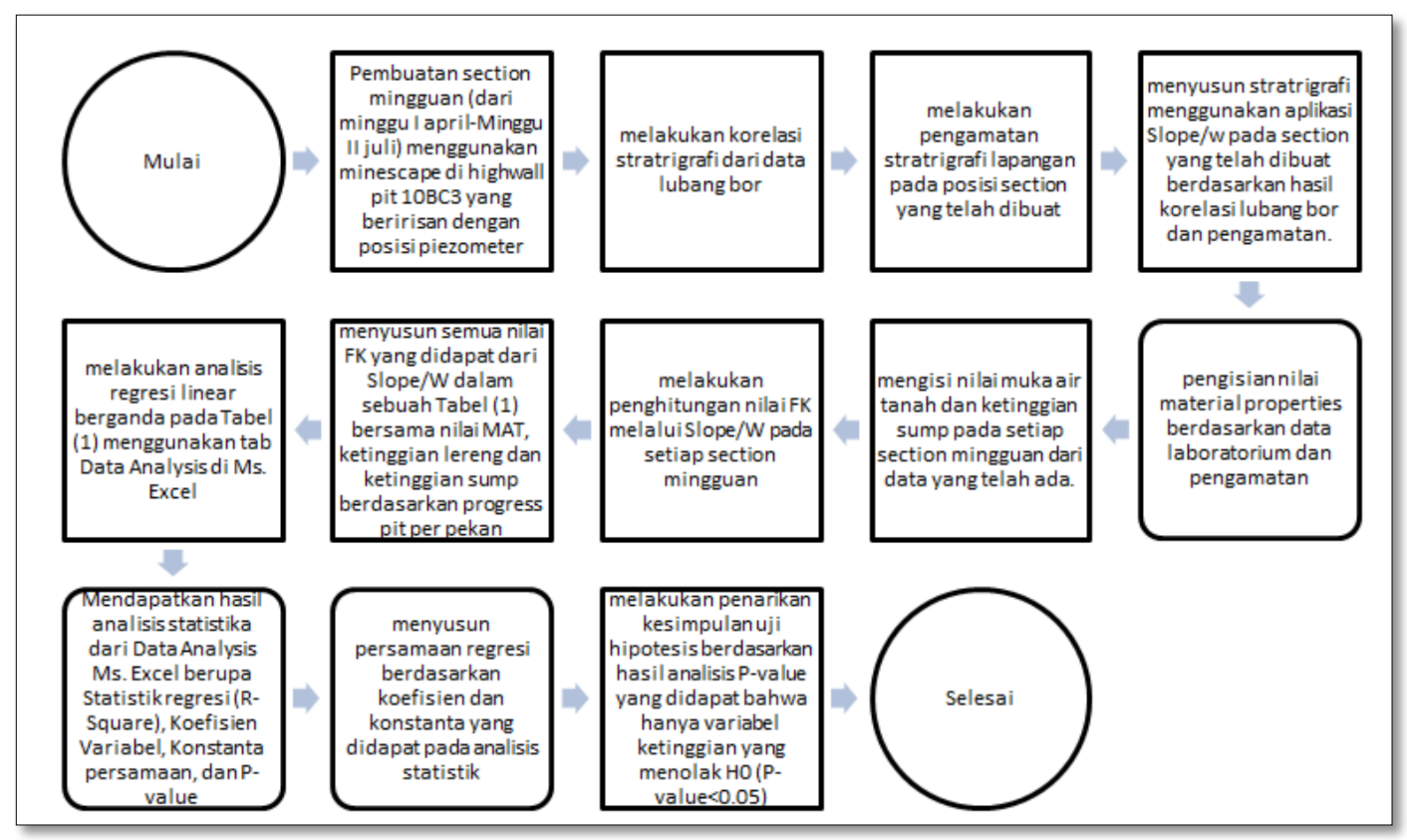

Gambar 4. Diagram Alir Penelitian

\section{HASIL \& PEMBAHASAN}

Dari pengambilan data sekunder berupa material properties, korelasi stratigrafi dari litologi titik2 bor yang tersebar, lalu pengambilan data topografi di awal periode penelitian (Gambar 5), didapatkan susunan stratigrafi pada area penelitian dapat dilihat pada Gambar 6 di bawah ini.

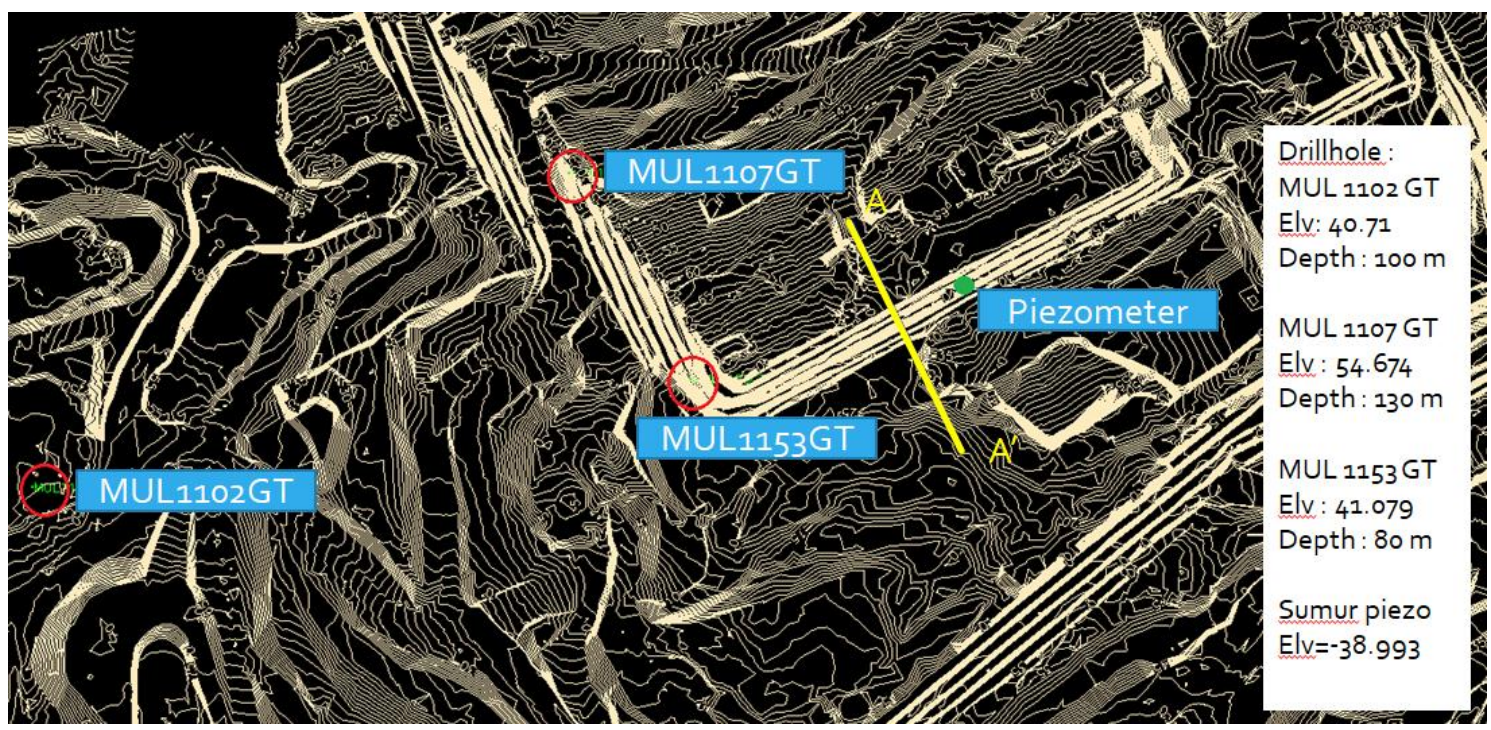

Gambar 5. Lokasi Sebaran Drillhole Geotek dan Garis Sayatan A-A' 


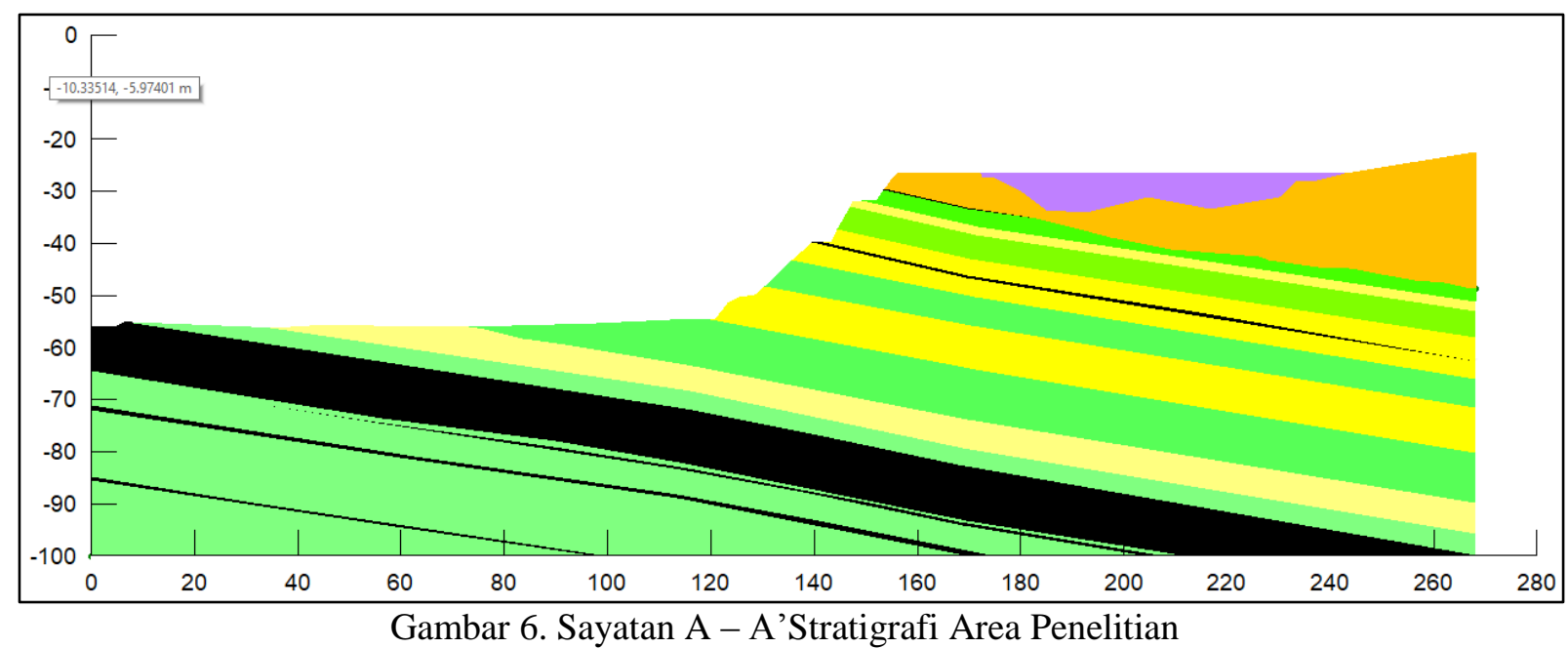

Hasil pengambilan data elevasi muka air tanah, elevasi air sump dan ketinggian lereng highwall dapat dilihat pada Tabel 1 sebagai berikut :

Tabel 1. Data Pengukuran Elevasi MAT, Elevasi Air Sump dan Ketinggian Highwall

\begin{tabular}{ccccc}
\hline Tanggal & Periode & $\begin{array}{c}\text { Elevasi } \\
\text { MAT }\end{array}$ & $\begin{array}{c}\text { Elevasi } \\
\text { Sump }\end{array}$ & $\begin{array}{c}\text { Tinggi } \\
\text { Lereng }\end{array}$ \\
\hline $4 / 08 / 2019$ & Week 1 & $-41,07$ & $-57,783$ & 28,184 \\
$4 / 15 / 2019$ & Week 2 & $-42,23$ & $-58,413$ & 32,787 \\
$4 / 22 / 2019$ & Week 3 & $-43,28$ & $-59,215$ & 33,878 \\
$4 / 29 / 2019$ & EOM April & $-44,33$ & $-59,308$ & 37,361 \\
$5 / 06 / 2019$ & Week 1 & $-45,38$ & $-58,811$ & 37,361 \\
$5 / 13 / 2019$ & Week 2 & $-45,95$ & $-58,967$ & 37,361 \\
$5 / 20 / 2019$ & Week 3 & $-46,29$ & $-58,853$ & 37,361 \\
$5 / 27 / 2019$ & EOM Mei & $-46,77$ & $-58,924$ & 41,293 \\
$6 / 10 / 2019$ & Week 1 & $-47,25$ & $-58,436$ & 41,293 \\
$6 / 17 / 2019$ & Week 2 & $-47,51$ & $-56,436$ & 41,293 \\
$6 / 24 / 2019$ & Week 3 & $-47,77$ & $-57,490$ & 41,293 \\
$7 / 01 / 2019$ & EOM Juni & $-47,80$ & $-57,019$ & 41,293 \\
$7 / 08 / 2019$ & Week 1 & $-47,86$ & $-59,292$ & 41,293 \\
$7 / 15 / 2019$ & Week 2 & $-47,91$ & $-61,299$ & 41,293 \\
\hline
\end{tabular}

Berdasarkan data variable-variabel di atas, dilakukan analisis kestabilan lereng pada area penelitian. Hasil dari analisis kestabilan lereng berupa nilai Faktor Keamanan pada tiap minggu. Dari analisis regresi didapatkan nilai koefisien dan $P$-value tiap variabel serta statistik regresi seperti pada Tabel 2 dibawah ini. 
Tabel 2. Nilai koefisien dan nilai P tiap variabel serta statistik regresi

\begin{tabular}{lrl}
\hline & Coefficients & P-value \\
\hline Intercept & 2,231392951 & 0,010731262 \\
MAT Level & $-0,008940248$ & 0,632701725 \\
Sump Elevation & 0,005915427 & 0,514617847 \\
Height & $-0,025973278$ & 0,026958875 \\
\hline \multicolumn{3}{c}{ Regression Statistics } \\
\hline Multiple $R$ & 0,936703377 \\
R Square & 0,877413216 \\
Adjusted R Square & 0,84063718 \\
Standard Error & 0,03722378 \\
Observations & 14 \\
\hline
\end{tabular}

Dari analisis regresi diatas didapatkan persamaan regresi untuk area penelitian sebagai berikut : Persamaan Regresi :

$$
\text { FK }=-0.0089 x+0.0059 y+-0.026 z+2,2314
$$

$\mathrm{x}=$ Elevasi MAT $(\mathrm{m})$

$\mathrm{y}=$ Elevasi Sump $(\mathrm{m})$

$\mathrm{z}=$ Tinggi Lereng $(\mathrm{m})$

P-value $>0.05=\mathrm{H} 0$ diterima

P-value $<0.05=\mathrm{H} 0$ ditolak atau H1 menolak H0

dengan ketentuan $\mathrm{H} 0=$ variabel tidak terlalu berpengaruh terhadap $\mathrm{FK}$ lereng dan $\mathrm{H} 1$ = variabel memiliki pengaruh terhadap FK lereng. Dari persamaan di atas dan dari nilai $P$-value yang didapat, variabel MAT memiliki nilai $P$-value 0.63 (> 0.05) sehingga H0 diterima. Variabel elevasi sump memiliki $P$-value $0.51(>0.05)$ sehingga $\mathrm{H} 0$ diterima serta variabel tinggi lereng memiliki $P$-value 0.026 ( $<0.05$ ) sehingga H0 ditolak sehingga dapat disimpulkan bahwa variabel yang paling berpengaruh terhadap nilai Faktor Keamanan adalah variabel Tinggi Lereng (Tabel 3)

Tabel 3. Rekapitulasi Variabel dan Status H0

\begin{tabular}{cccccc}
\hline \multicolumn{1}{c}{ Variabel } & Koefisien & P Value & Vs P Value & H0 & H0 Status \\
\hline Elevasi MAT (x) & -0.00894 & 0.63270 & $>0,05$ & Variabel tidak berpengaruh & Diterima \\
Elevasi Sump (y) & 0.00592 & 0.51462 & $>0,05$ & Variabel tidak berpengaruh & Diterima \\
Tinggi Lereng (z) & $\mathbf{- 0 . 0 2 5 9 7}$ & 0.02696 & $\mathbf{< 0 , 0 5}$ & Variabel tidak berpengaruh & Ditolak \\
\hline
\end{tabular}

Nilai Faktor Keamanan (FK) juga dianalisis mulai dari minggu pertama (minggu pertama April 2019) hingga minggu ke empat belas (minggu kedua Juli 2019). Trend dari nilai FK tersebut cenderung menunjukkan nilai penurunan (dimulai dengan nilai FK 1.51 di minggu 1, hingga FK dengan nilai 1.22 di periode akhir / minggu ke 14). Hal ini disebabkan oleh bekerjanya variabel beda tinggi lereng (nilai 
beda ketinggian semakin besar seiring dengan penurunan level tambang) seperti yang ditunjukkan oleh Tabel 4 sebagai berikut :

Tabel 4. Trend Nilai FK dan Beda Ketinggian

\begin{tabular}{cccc}
\hline TANGGAL & KETERANGAN & Height & FK \\
\hline $08 / 04 / 2019$ & Week 1 & 28,184 & 1,512 \\
$15 / 04 / 2019$ & Week 2 & 32,787 & 1,492 \\
$22 / 04 / 2019$ & Week 3 & 33,878 & 1,342 \\
$29 / 04 / 2019$ & EOM April & 37,361 & 1,285 \\
$06 / 05 / 2019$ & Week 1 & 37,361 & 1,306 \\
$13 / 05 / 2019$ & Week 2 & 37,361 & 1,317 \\
$20 / 05 / 2019$ & Week 3 & 37,361 & 1,323 \\
$27 / 05 / 2019$ & EOM Mei & 41,293 & 1,231 \\
$10 / 06 / 2019$ & Week 1 & 41,293 & 1,187 \\
$17 / 06 / 2019$ & Week 2 & 41,293 & 1,237 \\
$24 / 06 / 2019$ & Week 3 & 41,293 & 1,272 \\
$01 / 07 / 2019$ & EOM Juni & 41,293 & 1,259 \\
$08 / 07 / 2019$ & Week 1 & 41,293 & 1,266 \\
$15 / 07 / 2019$ & Week 2 & 41,293 & 1,24 \\
\hline
\end{tabular}

\section{E. KESIMPULAN}

1. Dari analisis regresi linier pada ketiga variabel yang bekerja (elevasi MAT, elevasi sump, ketinggian lereng), yang memiliki pengaruh terhadap Faktor Keamanan (FK) lereng adalah variabel ketinggian lereng.

2. Variabel ketinggian lereng mempunyai peranan terhadap nilai Faktor Keamanan (FK) lereng, dimana semakin tinggi beda tinggi, trend FK menunjukkan nilai yang semakin kecil.

\section{DAFTAR PUSTAKA}

Draper, Smith, Regression Analysis, 2011, Pearson Prentice $7^{\text {th }}$ Ed.

Hoek, E., \& Bray, J.W., 1981, Rock Slope Engineering $3^{\text {rd }}$ Ed., The Institution of Mining and Metallurgy, London

Hoek. E. 2000. Practical Rock Engineering. Ever Hoek Consulting Engineer Inc, Canada.

Rai, M.A., 1999, Analisis Kemantapan Lereng, Pendidikan dan Pelatihan Perencanaan Tambang Batubara dengan Tambang Terbuka Secara Terintegrasi, Pusat Antar Universitas Ilmu Rekayasa, Institut Teknologi Bandung, Jurusan Teknik Pertambangan, Bandung.

Sulistianto, B., 2006, Analisis Kemantapan Lereng, Kursus Singkat Geoteknik Terapan untuk Tambang Terbuka, Program Studi Teknik Pertambangan, Institut Teknologi Bandung, Bandung Wyllie, D.C., Mah, C.W., 2004, Rock Slope Engineering $4^{\text {th }}$ Ed., Spon Pres, London 


\section{LAMPIRAN}

\begin{tabular}{|c|c|c|c|c|c|c|c|c|c|c|c|c|c|c|}
\hline \multicolumn{2}{|c|}{ Depth } & \multirow{2}{*}{ Thickness } & \multirow{2}{*}{ Lithology } & \multirow{2}{*}{$\frac{c(\mathrm{Kpa})}{\text { Peak }}$} & \multirow{2}{*}{$\begin{array}{c}\Phi(\mathrm{deg}) \\
\text { Peak }\end{array}$} & \multirow{2}{*}{$\begin{array}{c}c(\mathrm{Kpa}) \\
\text { Residual }\end{array}$} & \multirow{2}{*}{$\begin{array}{c}\Phi(\text { deg) } \\
\text { Residual }\end{array}$} & \multirow{2}{*}{$\begin{array}{c}\text { Unit } \\
\text { Weight } \\
\text { (KN/M3) }\end{array}$} & \multirow{2}{*}{$\begin{array}{c}c(\mathrm{Kpa}) \\
\text { res }+20 \%\end{array}$} & \multirow{2}{*}{\begin{tabular}{c|}
$\Phi($ deg $)$ \\
res $+20 \%$
\end{tabular}} & \multirow{2}{*}{\begin{tabular}{|c|}
$c(\mathrm{Kpa})$ \\
res $+30 \%$ \\
\end{tabular}} & \multirow{2}{*}{\begin{tabular}{c|}
$\Phi($ deg $)$ \\
res $+30 \%$
\end{tabular}} & \multirow{2}{*}{\begin{tabular}{|c|}
$c(\mathrm{Kpa})$ \\
res $+50 \%$ \\
\end{tabular}} & \multirow{2}{*}{$\begin{array}{c}\Phi(\mathrm{deg}) \\
\text { res }+50 \%\end{array}$} \\
\hline From & To & & & & & & & & & & & & & \\
\hline Hole Nan & MUL1107GT & & & & & & & & & & & & & \\
\hline 4,67 & 5,17 & 0,50 & Siltsone & 122 & 29,38 & 63 & 18,13 & 21,8 & 75,6 & 21,756 & 81,9 & 23,569 & 94,5 & 27,195 \\
\hline 14,70 & 15,23 & 0,53 & Coal DL1 & 186 & 39,83 & 102 & 25,66 & 14,1 & 122.4 & 30,792 & 132,6 & 33,358 & 153 & 38,49 \\
\hline 21,26 & 21,78 & 0,52 & Claystone & 117 & 23,88 & 60 & 14,72 & 21,6 & 72 & 17,664 & 78 & 19,136 & 90 & 22,08 \\
\hline 24,75 & 25,13 & 0,38 & Coal DL.2 & 207 & 41,75 & 107 & 23,65 & 13,2 & 128,4 & 28,38 & 139,1 & 30,745 & 160,5 & 35,475 \\
\hline 34,68 & 35,20 & 0,52 & Claystone & 127 & 26,25 & 67 & 15,47 & 21,4 & 80,4 & 18,564 & 87,1 & 20,111 & 100,5 & 23,205 \\
\hline \multicolumn{15}{|c|}{ Hole Name MUL1153GT } \\
\hline 10,90 & 11,40 & 0,50 & Claystone & 122 & 26,34 & 57 & 14,07 & 21,5 & 68.4 & 16,884 & 74,1 & 18,291 & 85,5 & 21,105 \\
\hline 13,54 & 14,04 & 0,50 & $\begin{array}{c}\text { Carbonaceous } \\
\text { Claystone }\end{array}$ & 177 & 25,37 & 62 & 15,93 & 20,8 & 74,4 & 19,116 & 80,6 & 20,709 & 93 & 23,895 \\
\hline 29,00 & 29,50 & 0,50 & Claystone & 135 & 25,4 & 71 & 15,31 & 21,4 & 85,2 & 18,372 & 92,3 & 19,903 & 106,5 & 22,965 \\
\hline 34,50 & 35,00 & 0,50 & Sandstone 1 & 139 & 30,54 & 72 & 18,44 & 21,4 & 86,4 & 22,128 & 93,6 & 23,972 & 108 & 27,66 \\
\hline 48,65 & 49,15 & 0,50 & Coal & 197 & 39,99 & 96 & 24,92 & 13,5 & 115,2 & 29,904 & 124,8 & 32,396 & 144 & 37,38 \\
\hline 55,74 & 56,24 & 0,50 & Claystone sisip & 141 & 26,38 & 75 & 16,36 & 21,3 & 90 & 19,632 & 97,5 & 21,268 & 112,5 & 24,54 \\
\hline 56,70 & 57,12 & 0,42 & Coal DL.3 & 172 & 43,21 & 90 & 25,48 & 14,0 & 108 & 30,576 & 117 & 33,124 & 135 & 38,22 \\
\hline 73,10 & 73,60 & 0,50 & Claystone 1 & 140 & 24,69 & 76 & 14,93 & 21,1 & 91,2 & 17,916 & 98,8 & 19,409 & 114 & 22,395 \\
\hline 78,25 & 78,70 & 0,45 & Sandstone 2 & 144 & 34,05 & 80 & 20,58 & 24,3 & 96 & 24,696 & 104 & 26,754 & 120 & 30,87 \\
\hline \multicolumn{15}{|c|}{ Hole Name MUL1102GT } \\
\hline 9,10 & 960 & 0,50 & Claystone 2 & 109 & 23,55 & 60 & 14,04 & 209 & 72 & 16,848 & 78 & 18,252 & 90 & 2106 \\
\hline 18,05 & 18,60 & 0,55 & Claystone 3 & 127 & 24,40 & 69 & 14,36 & 21,1 & 82,8 & 17,232 & 89,7 & 18,668 & 103,5 & 21,54 \\
\hline 32,22 & 32,42 & 0,20 & Coally Shale & 133 & 26,83 & 71 & 16,39 & 14,3 & 85,2 & 19,668 & 92,3 & 21,307 & 106,5 & 24,585 \\
\hline 51,70 & 52,20 & 0,50 & Sandstone 3 & 149 & 33,84 & 82 & 20,61 & 23,3 & 98,4 & 24,732 & 106,6 & 26,793 & 123 & 30,915 \\
\hline 60,23 & 60,73 & 0,50 & Sandstone 4 & 123 & 30,59 & 66 & 19,15 & 23,4 & 792 & 22,98 & 85,8 & 24,895 & 99 & 28,725 \\
\hline 61,74 & 62,24 & 0,50 & Claystone 4 & 142 & 27,38 & 75 & 15,21 & 20,4 & 90 & 18,252 & 97,5 & 19,773 & 112,5 & 22,815 \\
\hline 70,47 & 70,97 & 0,50 & Claystone 5 & 137 & 24,36 & 72 & 17,1 & 20,4 & 86,4 & 20,52 & 93,6 & 22,23 & 108 & 25,65 \\
\hline 72,20 & 72,73 & 0,53 & Sandstone 5 & 144 & 31,26 & 79 & 18,52 & 23,3 & 94,8 & 22,224 & 102,7 & 24,076 & 118,5 & 27,78 \\
\hline 80,20 & 80,70 & 0,50 & Coal EU1 & 240 & 41,76 & 104 & 23,38 & 14,9 & 124,8 & 28,056 & 135,2 & 30,394 & 156 & 35,07 \\
\hline 95,95 & 96,45 & 0,50 & Sandstone & 155 & 32,97 & 85 & 21,6 & 23,2 & 102 & 25,92 & 110,5 & 28,08 & 127,5 & 32,4 \\
\hline 97,51 & 98,04 & 0,53 & Siltsone & 139 & 28,30 & 66 & 18,69 & 20,4 & 79,2 & 22,428 & 85,8 & 24,297 & 99 & 28,035 \\
\hline
\end{tabular}

Lampiran 1. Material Properties Area Penelitian

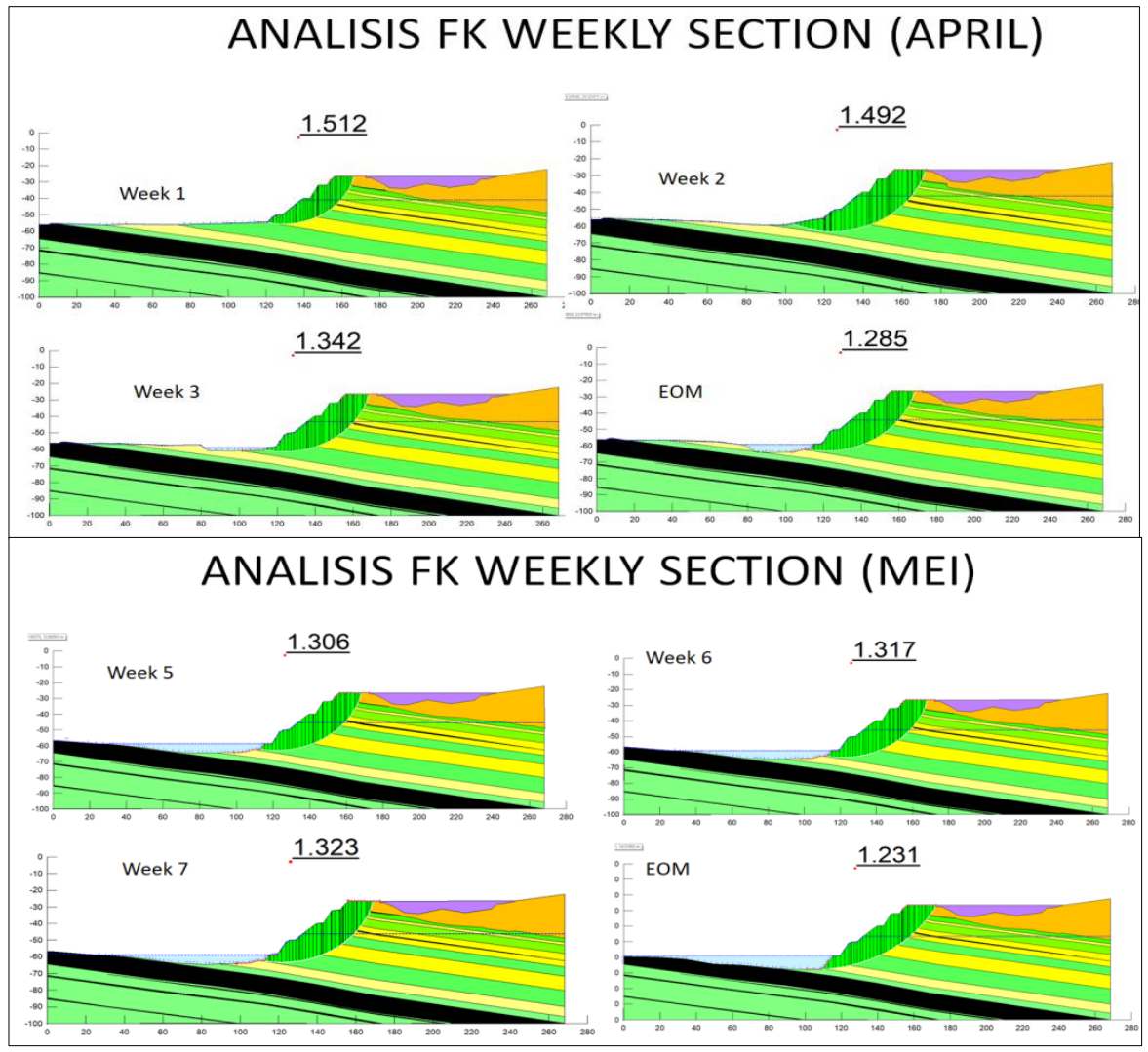

Lampiran 2. Analisis FK Week 1 - Week 8 


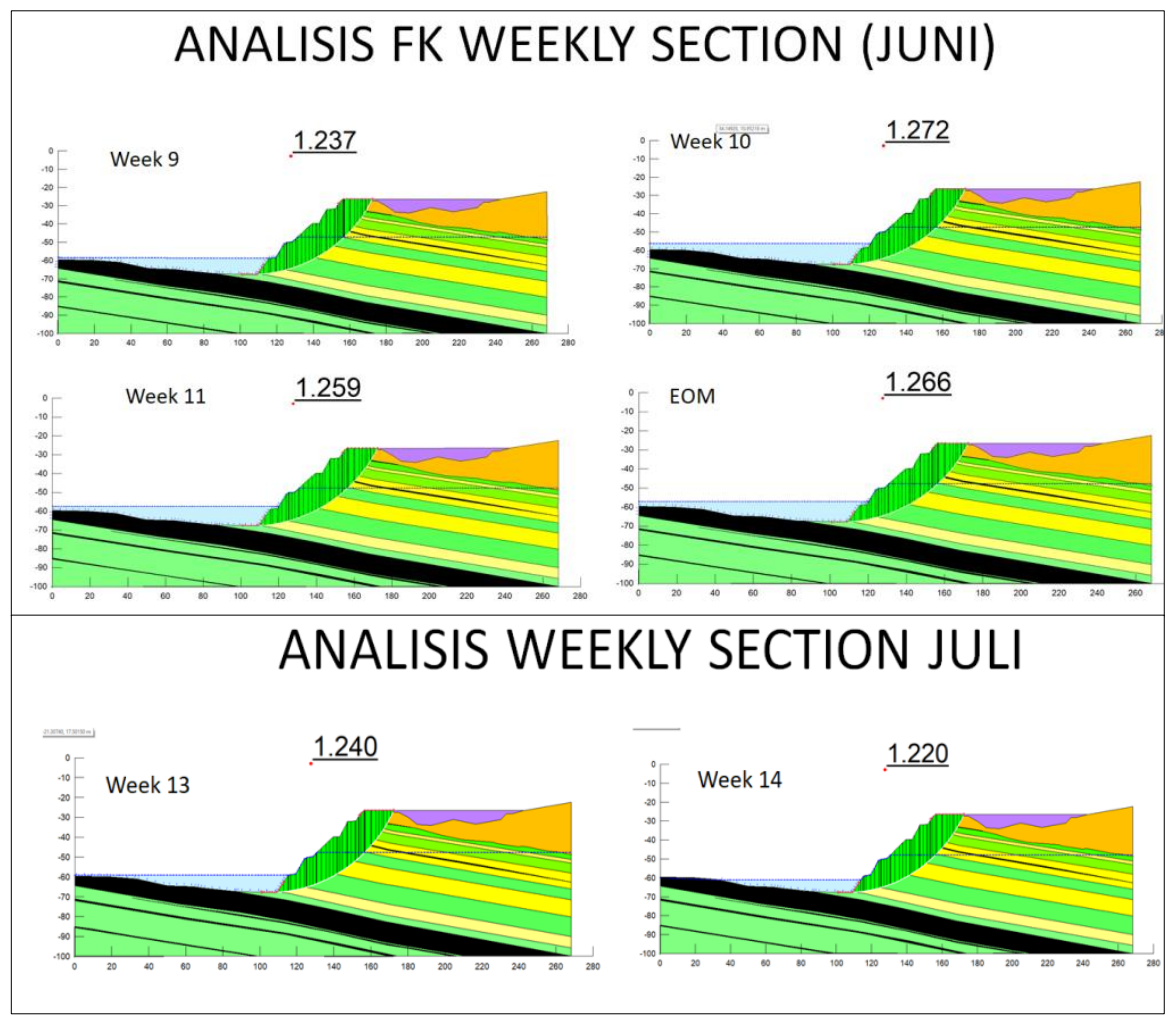

Lampiran 3. Analisis FK Week 9 - Week 14

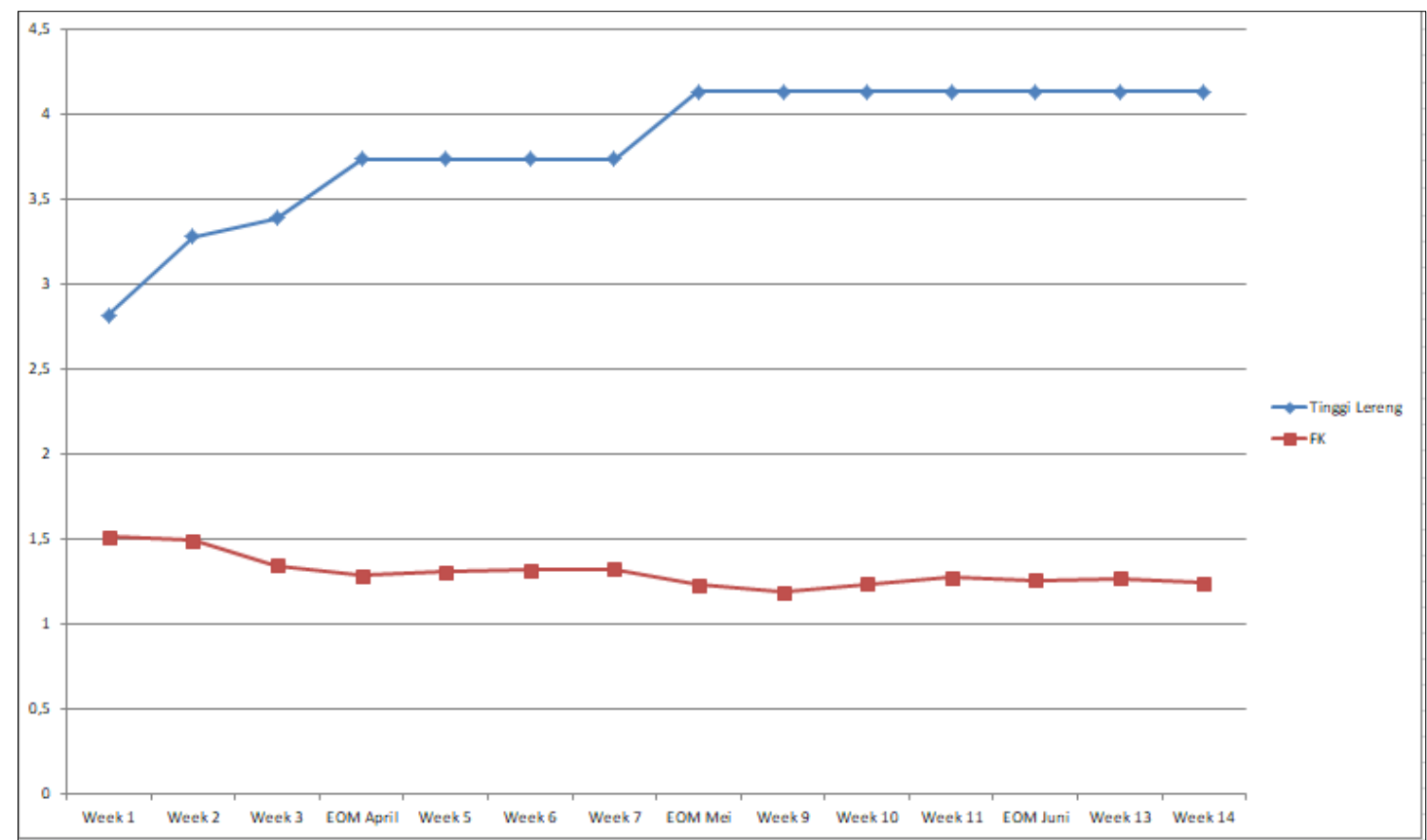

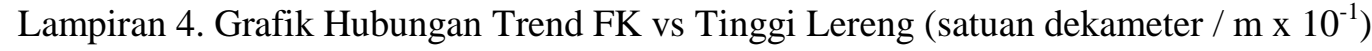

